\title{
Prefiguring Issues of SMEs Readiness in Malaysia as the Future of Industry 4.0 Unfolds
}

Mira Qerul Barriah Muhamad, Syed Jamal Abdul Nasir Syed Mohamad and Norzanah Mat Nor

To Link this Article: http://dx.doi.org/10.6007/IJARBSS/v10-i12/7635

DOI:10.6007/IJARBSS/v10-i12/7635

Received: 05 November 2020, Revised: 30 November 2020, Accepted: 15 December 2020

Published Online: 29 December 2020

In-Text Citation: (Muhamad et al., 2020)

To Cite this Article: Muhamad, M. Q. B., Mohamad, S. J. A. N. S., \& Nor, N. M. (2020). Prefiguring Issues of SMEs Readiness in Malaysia as the Future of Industry 4.0 Unfolds. International Journal of Academic Research in Business and Social Sciences, 10(12), 1283-1292.

Copyright: (c) 2020 The Author(s)

Published by Human Resource Management Academic Research Society (www.hrmars.com) This article is published under the Creative Commons Attribution (CC BY 4.0) license. Anyone may reproduce, distribute, translate and create derivative works of this article (for both commercial and non-commercial purposes), subject to full attribution to the original publication and authors. The full terms of this license may be seen at: http://creativecommons.org/licences/by/4.0/legalcode

Vol. 10, No. 12, 2020, Pg. 1283 - 1292

Full Terms \& Conditions of access and use can be found at http://hrmars.com/index.php/pages/detail/publication-ethics 


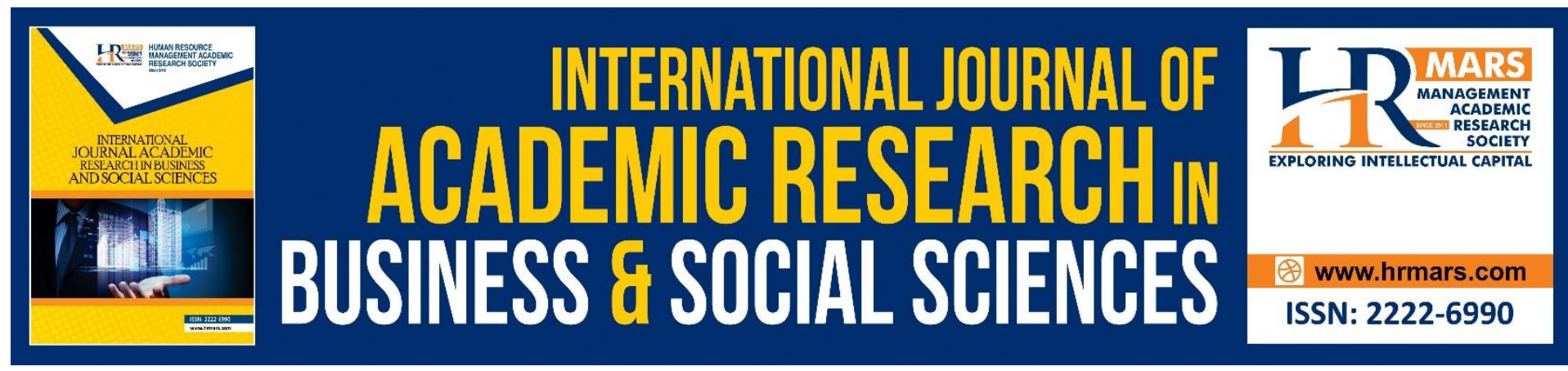

\title{
Prefiguring Issues of SMEs Readiness in Malaysia as the Future of Industry 4.0 Unfolds
}

\author{
Mira Qerul Barriah Muhamad ${ }^{1}$, Syed Jamal Abdul Nasir Syed \\ Mohamad ${ }^{2}$ and Norzanah Mat $\mathrm{Nor}^{3}$ \\ ${ }^{1}$ Faculty of Business and Management, Universiti Teknologi Mara, 40450 Shah Alam, \\ Selangor, ${ }^{2}$ Arshad Ayub Graduate Business School (AAGBS), Universiti Teknologi Mara, \\ 40450 Shah Alam, Selangor, ${ }^{3}$ Arshad Ayub Graduate Business School (AAGBS), Universiti \\ Teknologi Mara, 40450 Shah Alam, Selangor. \\ Email:myraqerul@gmail.com, syedjamal145@uitm.edu.my, norzanah@uitm.edu.my
}

\begin{abstract}
The topic of Industry 4.0 in regard to small and medium-sized enterprises (SMEs hereafter) have been exponentially debated among scholars up to this date. Industry 4.0 technology offers competitive tools to firms that help facilitate corporate resilience and cope with expiry business models. The ideology particularly dominates on automation in manufacturing that imperative for national economy awakening. In light of the modern state, technological business orientation must be meticulously deliberated, replacing the traditional one. SMEs in Malaysia are seen as not receptive when it comes to aligning businesses with coherent technology advancement. The issues on Industry 4.0 readiness among Malaysian SMEs have been listed by the Ministry of Trade and Industry in their report. Growing evidence shows high-tech technology has a positive relationship with organization performance. Thus, the pitfalls inhibit the development should be obliterated to achieve the idealism country we espouse.
\end{abstract}

Keywords: Industry 4.0, Readiness, SMEs, Digitalization, Malaysia.

\section{Introduction}

The latest technological advancement that put together computers and automation to work in a distinctive way is called The Fourth Industrial Revolution or Industry 4.0 (naming convention per se). It is the convergence of many significant technologies, ready to transform various industries. Whilst digitalization is characterized as reconstructing of the business operation, including consumer management, goods and services and transaction in digital world. Industry 4.0 has greatly impacted global economy, resulting in progression of several countries' development.

As technology keeps advancing at an accelerated rate, SMEs need to diligently work on restoration plans to mobilize Industry 4.0 technology under uncertain economic realm. In this progressive and dynamics business landscape, SMEs should acknowledge the importance of jumping into Industry 4.0 bandwagon rather than retaining themselves in old-fashioned business practices. Existing literatures have widely discussed on perks brought by this 
megatrend. Therefore, it is integral for SMEs to take advantage of the possibilities emerging from Industry 4.0 as their business will benefit greatly. Jesus \& Lima (2020) believed organization will be able to compete intensely with the high-tech technology and connectivity services of the Industry 4.0 .

\section{Industry 4.0 in Malaysian SMEs}

For the past few years, Malaysia is undeniably taking significant steps improving its domestic market environment for SMEs. The National eCommerce Strategic Roadmap, Digital Free Trade Zone, SME Masterplan (2012-2020), National Entrepreneurship Framework (NEF) and Shared Prosperity Vision 2030 are among few programmes executed by the government in supporting SMEs to endeavour their business domestically and globally. The transition driven by digitization 4.0 paves the way for renewable resource transformation and contributes to sustainable nation growth.

SMEs have started out as one of the country's biggest contributors, responsible for over onethird of Malaysia's economy, consequently being a substantive focus of the government. In line with the presence of Industry 4.0, Malaysian government has intensely stepping up SMEs competitiveness with intensification efforts by introducing several blueprints and incentives in the form of financial integrate with technological support to encourage SMEs expanding their market and economic growth. For example, the government already proposed SME Masterplan 2.0 (2021-2030) that will be focusing on stimulating SMEs endeavour in an internationalized and digital marketplace. The Masterplan also underscore on orientating business strategy of SMEs to adapt with the digitalization of Industry 4.0.

In Asia, the definition of SMEs varies over one country to another as it is defined based on some criteria. A revised classification of small and medium-sized businesses has been done but the criteria for number of employees and sales turnover are remained even the threshold has been raised to;

(i) Manufacturing sector: Sales turnover not surpassing RM50 million or full-time employees not surpassing 200 people;

(ii) Services and other sectors: Sales turnover not surpassing RM20 million or full-time employees not surpassing 75 people (SME Corporation Malaysia, 2018).

Detailed definition of SMEs is shown in Table 1.

Table 1

SME Definition in Malaysia

\begin{tabular}{|c|c|c|c|c|c|c|}
\hline \multirow{2}{*}{ Size } & \multicolumn{2}{|c|}{ Micro } & \multicolumn{2}{|c|}{ Small } & \multicolumn{2}{|c|}{ Medium } \\
\hline & $\begin{array}{c}\text { Sales } \\
\text { Turnover }\end{array}$ & $\begin{array}{c}\text { Employee } \\
\mathrm{s}\end{array}$ & $\begin{array}{c}\text { Sales } \\
\text { Turnover }\end{array}$ & $\begin{array}{c}\text { Employee } \\
\mathrm{s}\end{array}$ & $\begin{array}{c}\text { Sales } \\
\text { Turnove } \\
r\end{array}$ & $\begin{array}{c}\text { Employee } \\
\mathrm{s}\end{array}$ \\
\hline $\begin{array}{l}\text { Manufacturin } \\
\text { g }\end{array}$ & $\begin{array}{c}<\mathrm{RM} 300,00 \\
0\end{array}$ & $\begin{array}{c}<5 \\
\text { employee }\end{array}$ & $\begin{array}{c}\text { RM300,00 } \\
0 \\
\text { to }<15 \\
\text { million }\end{array}$ & $\begin{array}{c}5 \text { to }<75 \\
\text { employee } \\
\mathrm{s}\end{array}$ & $\begin{array}{l}\text { RM15 } \\
\text { million } \\
\text { to } \leq 50 \\
\text { million }\end{array}$ & $\begin{array}{c}75 \text { to } \\
\leq 200 \\
\text { employee } \\
\mathrm{s}\end{array}$ \\
\hline $\begin{array}{l}\text { Services \& } \\
\text { other sectors }\end{array}$ & & s & $\begin{array}{c}\mathrm{RM} 300,00 \\
0 \\
\text { to } \\
<3 \text { million }\end{array}$ & $\begin{array}{c}5 \text { to }<30 \\
\text { employee } \\
\mathrm{s}\end{array}$ & $\begin{array}{l}\text { RM3 } \\
\text { million } \\
\text { to } \leq 20 \\
\text { million }\end{array}$ & $\begin{array}{c}30 \text { to } \leq 75 \\
\text { employee } \\
\mathrm{s}\end{array}$ \\
\hline
\end{tabular}

Source: SME Corporation Malaysia (2018) 
SMEs in Association of Southeast Asian Nations (ASEAN) countries - Singapore, Brunei, Malaysia, Thailand, Philippines, Indonesia, Vietnam, Laos, Cambodia, Myanmar are representing around $97 \%-99 \%$ from the whole business community (Asian Development Bank, 2018). For the record, in Malaysia alone $98.5 \%$ of business establishments are made up of SMEs cut across all sized and sectors recorded up to $38.9 \%$ contribution to Malaysia's GDP in 2019 compared to $38.3 \%$ in 2018 , as well as growth in gross in exports increased to $17.9 \%$ in 2019 compared to $17.3 \%$ in 2018 and lastly a growing in employment rate from $48 \%$ in 2018 to $48.4 \%$ in 2019 (SME Corporation Malaysia, 2020). Figure 1 illustrates the GDP performance of SMEs in Malaysia.

Figure 1: SME Performance in 2019

\begin{tabular}{|c|c|c|}
\hline $\begin{array}{l}\text { SME } \\
\text { GDP }\end{array}$ & $\begin{array}{c}\text { SME } \\
\text { Exports }\end{array}$ & $\begin{array}{c}\text { SME } \\
\text { Employment }\end{array}$ \\
\hline $\begin{array}{l}\text { RM552.3 bil } \\
\text { [38.9\% share] }\end{array}$ & $\begin{array}{l}\text { RM176.3 bil } \\
\text { [17.9\% share] }\end{array}$ & $\begin{array}{l}7.3 \text { mil workers } \\
\text { [48.4\% share]* }\end{array}$ \\
\hline $\begin{array}{l}\text { (2018: RM522.1 bil) } \\
\text { [38.3\% share] }\end{array}$ & $\begin{array}{c}\text { (2018: RM171.8 bil) } \\
{[17.3 \% \text { share] }}\end{array}$ & $\begin{array}{c}\text { (2018: } 7.1 \text { mil workers) } \\
\text { [48.0\% share]* }\end{array}$ \\
\hline
\end{tabular}

Source: Department of Statistics, Malaysia (2020)

SME Corporation Malaysia (2017) projected all SMEs in the country to implement digitalization business activities within five years relative to current performance. Malaysian SMEs however seem hesitant in taking the plunge although larger firms are promptly prepared for the efficiency gains from the sophisticated technologies of Industry 4.0 (Ministry of Trade and Industry, 2018). Radzi \& Wahab (2017) concluded in their study that due to technology incompetence among Malaysian SMEs, it caused them to produce low performance in business.

The implementation and integration of Industry 4.0 technologies seem to be particularly difficult for SMEs to incorporate (Issa, Hatiboglu, Bildstein, \& Bauernhansl, 2018; Muller 2019). Most scholars firmly believed Industry 4.0 are deliberated for multi-national enterprises (MNEs) or larger organizations (Mittal, Khan, Romero \& Wuest, 2018). Stenfort, Rajkumar \& Madsen (2017) highlighted there has been a study found that SMEs tend to be not capable of perceiving Industry 4.0 compared to bigger businesses, which is supported by Matt \& Raunch (2020) as they opined the smaller the SMEs, the harder to exploit the benefits available. Large companies on the other hand, often accommodate with appropriate number of resources, finest facility and maintain high degree of specialisation. Therefore, the transition process would be less complicated.

\section{Issues on SMEs Readiness}

Ministry of Trade and Industry (2018) in their report has stressed on the challenges and issues faced by SMEs before decided on harnessing Industry 4.0 in their business operations. Among the pitfalls identified are the level of awareness, innovation management, the digital readiness and connectivity, the enhancement of skill needed, expensive cost of start-up and best practices understanding. 


\section{Awareness Level}

According to Abdullah, Abdullah \& Salleh (2017), the Malaysian government have not done enough in advocating the importance of Industry 4.0 in the mainstream, hence we have yet to see the acceptance by the people on a grander scale. The researchers also pointed out that there is no doubt a greater awareness among people with critical consciousness of media and information and communication technology are noticed but their participation in the transformation is yet to be determined. SME Corporation Malaysia has conducted a survey called The Third Quarter 2017 (3Q 2017) involving 1469 respondents focusing on the awareness and readiness status of Industry 4.0.

According to this survey, it shows that only $31.8 \%$ of the respondents are aware on the presence of Industry $4.0,69 \%$ are ready to embrace it, $66.4 \%$ are expecting a growth in productivity and efficiency from industry application while $62.1 \%$ agreed that limited knowledge and skills of employees is the biggest challenge (SME Corporation Malaysia, 2017). Figure 2 illustrated the results of the survey. The awareness level towards Industry 4.0 in this country is still insufficient to compare with SMEs in developed countries. Even the business owners are cautious on the comforting prospects, yet they brush aside the idealism due to various barriers and deficiency of resources and work skills.

Figure 2: Awareness of Industry 4.0

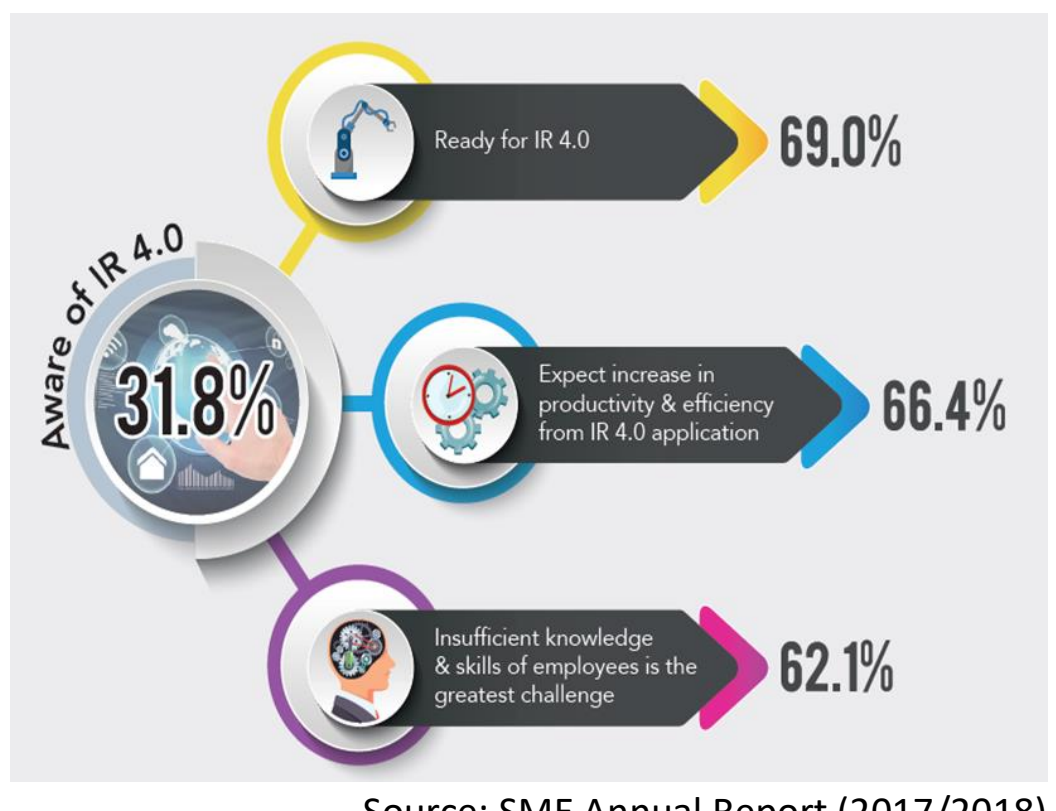

Innovation Management

Innovation has always been a prominent catalyst for any organization to assimilate automation orientation ingrained in Industry 4.0 to stay competitive and relevant. An organization might find the difficulty in sustaining its creativity and competitive advantage without a solid innovative culture nurtured among its workers. Innovation is crucial in any organization to cope with changes that occur at any time. The management of innovation can be defined as the process of organizing idea before it can be developed into the form of products or services, and then promoting them across stages of the production of new products or services before eventually selling them (Kowang et. al, 2019). Over the years, the 
performance of Malaysian SMEs has been severely affected in local and foreign markets due to the failure of instilling and practising open innovation systems (Hameed, Basheer, Iqbal, Anwar \& Ahmad, 2018). Malaysia is ranked at $72^{\text {nd }}$ in term of business innovation according to report of global innovation index.

\section{Digital Readiness and Connectivity}

The key to opening up potential of the digital economics is to ensure Malaysia's digital infrastructure provides an all-round, secure and ultra-fast broadband internet service. The Malaysian Manufacturers Federation (FMM) states that small companies struggle to navigate their way around innovations that ideal for their needs. "Malaysia's manufacturing readiness to embrace Industry 4.0 depends upon multiple variables, including the nature of the organization, its goods and services, and its business model. While Industry 4.0 is now being adopted by most international and larger corporations, most SMEs are yet still thoroughly scrutinizing and recognizing any of the Industry 4.0 practices that could be adopted in their operations." (Lee, 2018).

ICT acceptance is determined by the scale and business operation of the company. SocioEconomic Research Centre (2017) in their survey found that there is minimal usage of specialised ICT applications in Malaysia with just $16 \%$ of respondents stated that they are actually utilising e-commerce, while $11 \%$ said their companies would still be functioning even without the implementation of e-business.

\section{Skill of Enhancement}

A shortage in human capital is Malaysia's greatest hurdle to engage digital economic growth (World Bank Group, 2018). A limitation of digital literacy has been debated by many literatures as a primary obstacle to economic reforms. The education system and workforce training initiatives in Malaysia do not yet prepare adequate qualified employees to fulfil the growing demands of the digital economy. A study by Fetterman, Cavalcante, Almeida \& Tortorella (2018) also agreed demand for highly skilled labour has been one of the biggest challenges in implementing Industry 4.0 technologies in developing countries.

Up to this date, the industries of Malaysia are overly reliant on semi- and low-skilled employees and foreign labour (Ministry of Economic Affairs, 2018). The share of semi-skilled workers is the highest which made up of $62.3 \%$, followed by high-skilled workers which is only $24.4 \%$ (consist of people who are working in managerial, professional or technical roles) and 13.3\% low-skilled workers (Department of Statistics Malaysia, 2020). Asian Productivity Organization (2019) in their report highlighted that Malaysian SMEs would choose to minimize their expenses by employing additional cheap workers to do basic tasks such as packaging rather than taking the risk to invest in the realm of advanced technology.

\section{High Cost of Investment}

The access to investments and the return upon investment are strongly important to all type of businesses. SMEs are commonly owned by an individual with various obstacles are associated within the bound of small-scale operations. Industry 4.0 requires an upgrade in current system installation and in some cases, involve a whole new set-up of IT system. However, the cost is a crucial consideration to reckon with to SMEs in deciding whether to upgrade the current IT infrastructure or to build and implement the new one. Developing countries cannot afford to focus on marketing parts like developed countries did when it 
comes to digitalization because their main focus in most cases is financial goals (Bogoviz, Osipov, Chistyakova, \& Borisov, 2019).

Owners agreed that emerging technology requires more money and they may not have enough budget to make drastically improvements due to their strict budget dilemma (Harik, Hachem, Medini \& Bernard 2015). The expensive high technology-based and neglect of its return are the main reason rendering small businesses from being persuaded. One of the main reasons impeding business growth in Malaysia is the access to capital (World Bank Group, 2018). According to the World Bank Enterprise Survey, about half of firms in Malaysia voted access to capital as a moderate to very severe problem, on which the amount surpassing $35 \%$.

\section{Best Practices Understanding}

Ministry of International Trade and Industry (2018) in their report proposed the definition of best practices in this context as centralized knowledge systems that are readily available to grasp best practises and applicable implementations. Apparently, success stories of local companies implementing Industry 4.0 are minimal. The best practices should not only by advocating on the awareness by government, whose job is also to establish programmes and provide financial incentives to alleviate SMEs burden, but also to organizations to become self-reliance in utilizing diverse range of resources and discerning over opportunities created for them.

\section{Conclusion}

Looking at the current scenario, it can be concluded that SMEs in Malaysia are not ready for the implementation of Industry 4.0 despite various incentives and support provided by the government. Low level of awareness towards Industry 4.0 among SMEs, absence of innovation engagement in most small organizations, shortage of high-skill workers, limited resources and insufficient funding for advance technology are among the challenges restraining SMEs from enforcing the forthcoming technology as envisioned by the Malaysian government. In current dynamic and demanding market, SMEs should work on their ways in overcoming the challenges in order for them to sustain their businesses. The more prepared an organization is, the greater the use of technology is deemed to be important to its industry. It requires a sustained endeavour, consistent and persistent educative act. At the end of the day, their survival depends on their ability adapting to modern technologies. The economic effects of the unforeseen Covid-19 pandemic and the introduction of the Movement Control Order (MCO) will certainly impact SMEs performance in 2020. Department of Statistics Malaysia (2020) has predicted a negative contribution from all sectors to the growth of country GDP in 2020 plus gross exports also has been affected badly.

\section{Recommendations}

To overcome the issues aforementioned, SMEs must build digital skills and create the required digital confidence which plays an important role in harness customer value and retain competitive advantage in the market. Not only that, SMEs presuppose to evolve and transform their existing market activities, build skills and constantly update to emerging technologies (Nguyen \& Luu, 2020). This in return, would offer strategic advantage needed to succeed in changing business environment. SMEs in Malaysia must change and embrace Industry 4.0 to sustain their future production competitiveness. Or else, their global competitiveness may be jeopardised. 
Besides, it is suggested that formulating a better policy and regulations may increase the participation of SMEs towards Industry 4.0. This will result to SMEs producing better quality of products and services to compete in the market. The policy also should be reviewed and modified accordingly from time to time. Policymakers play a critical role in determining the execution of the blueprints and ensure appropriate technologies are in place to allow the industry step ahead through digitalization. In order to alleviate SMEs burden during the pandemic of Covid-19, The Malaysia Digital Economy Corporation (2020), a body established by the government as one of the digital strategies, provided SMEs with various digital solutions.

\section{References}

Abdullah, D., Abdullah, M. Y., \& Salleh, M. A. M. (2017). A review on the concept of fourth industrial revolution and the government's initiatives to promote it among youths in Malaysia. Journal of Social Sciences and Humanities, 1-8.

Asian Development Bank. (2018). Small and Medium-Sized Enterprises in Asia and the Pacific: Context and Issues. Retrieved from https://www.adb.org/sites/default/files/linkeddocuments/A-SME-Context-and-Issues.pdf

Asian Productivity Organization. (2019). Gearing Up to Industry 4.0 Digitization Strategies for SMEs. Retrieved from https://www.apo-tokyo.org/publications/wpcontent/uploads/sites/5/Gearing-Up-To-Industry-4.0-Digitization-Strategies-forSMEs.pdf

Bogoviz, A. V., Osipov, V. S., Chistyakova, M. K., \& Borisov, M. Y. (2019). Comparative analysis of formation of industry 4.0 in developed and developing countries. Studies in Systems, Decision and Control, 169, 155-164. https://doi.org/10.1007/978-3-319-94310-7_15

Büchi, G., Cugno, M., \& Castagnoli, R. (2020). Smart factory performance and Industry 4.0. Technology Forecasting and Society Change, 150, 1-10. https://doi.org/10.1016/j.techfore.2019.119790

Chiarini, A., Belvedere, V., \& Grando., A. (2020). Industry 4.0 strategies and technological developments. An exploratory research from Italian manufacturing companies. Production Planning \& Control, 31(16), 1385-1398. https://doi.org/10.1080/09537287.2019.1710304

Department of Statistics Malaysia. (2020). Employment Statistics Second Quarter 2019. Retrieved from

https://www.dosm.gov.my/v1/index.php?r=column/cthemeByCat\&cat=439\&bul_id=Y1A1W U14RG1ZRURxNkdkeHRMQjhjZz09\&menu_id=Tm8zcnRjdVRNWWIpWjRlbmtlaDk1UT0 9

Department of Statistics Malaysia. (2020). Malaysia Economic Performance Third Quarter 2020. Retrieved from https://www.dosm.gov.my/v1/index.php?r=column/cthemeByCat\&cat=100\&bul_id=Z IRNZVRDUmNzRFFQQ29IZXJoVOUxQT09\&menu_id=TE5CRUZCblh4ZTZMODZIbmk2aW RRQT09

Department of Statistics Malaysia. (2020). Small and Medium Enterprises (SMEs) Performance in 2019. Retrieved from https://www.dosm.gov.my/v1/index.php?r=column/cthemeByCat\&cat=159\&bul_id=V jM1enZ2RmIVRDVTNFAwRWZiZUs3QT09\&menu_id=TE5CRUZCblh4ZTZMODZIbmk2a WRRQT09 
Fetterman, D. C., Cavalcante, C. G., Almeida, T. D. D., \& Tortorella, G. L. (2018). How does industry 4.0 contribute to operations management? Journal of Industrial and Production Engineering, 1-14. https://doi.org/10.1080/21681015.2018.1462863

Hameed, W. U., Basheer, M. F., Iqbal, J., Anwar, A., \& Ahmad, H. K. (2018). Determinants of firm's open innovation performance and the role of R\&D department: an empirical evidence from Malaysian SME's. Journal of Global Entrepreneurship Research, 8(29), 120. https://doi.org/10.1186/s40497-018-0112-8

Harik, R., El Hachem, W., Medini, K., \& Bernard, A. (2015). Towards a holistic sustainability index for measuring the sustainability of manufacturing companies. International Journal of Production Research, 53(13), 4117-4139. https://doi.org/10.1080/00207543.2014.993773

Issa, A., Hatiboglu, B., Bildstein, A., \& Bauernhansl., T. (2018). Industrie 4.0 Roadmap: Framework for Digital Transformation Based on the Concepts of Capability Maturity and Alignment. Procedia CIRP, 72, 973-978. https://doi.org/10.1016/j.procir.2018.03.151

Jesus, C. D., \& Lima, R. M. (2020). Literature Search of Key Factors for the Development of Generic and Specific Maturity Models for Industry 4.0. Applied Sciences MDPI, 10, 1-19. https://doi.org/10.3390/app10175825

Kowang, T. O., Ying, Y. C., Yew, L. K., Hee, O. C., Fei, G. C., Long, C. S., \& Saadon, M. S. I. bin. (2019). Industry 4.0 Competencies for Production Equipment Manufacturers in Malaysia. International Journal of Academic Research in Business and Socal Sciences, 9(2), 300-311. http://dx.doi.org/10.6007/IJARBSS/v9-i2/5545

Malaysia Digital Economy Corporation. (2020). C19 Tech Relief. Retrieved from https://mdec.my/home/c19techrelief/

Ministry of Economic Affairs. (2018). Mid-Term Review of the Eleventh Malaysia Plan, Economic Planning Unit, Ministry of Economic Affairs, Putrajaya.

Ministry of International Trade and Industry. (2018). Industry4WRD National Policy on Industry 4.0. Retrieved from https://www.miti.gov.my/miti/resources/National\%20Policy\%20on\%20Industry\%204. 0/Industry4WRD_Final.pdf

Mittal, S., Khan, M. A., Romero, D., \& Wuest, T. (2018). A critical review of smart manufacturing \& Industry 4.0 maturity models: Implications for small and medium sized enterprises (SMEs). Journal of Manufacturing Systems, 49, 194-214. https://doi.org/10.1016/j.jmsy.2018.10.005

Moeuf, A., Pellerin, R., Lamouri, S., Tamayo-Giraldo, S., \& Barbaray, R. (2018). The Industrial Management of SMEs in the Era of Industry 4.0. International Journal of Production Research, 56 (3), 1118-1136. https://doi.org/10.1080/00207543.2017.1372647

Muller, J. M. (2019). Business Model Innovation in Small- and Medium-Sized Enterprises. Journal of Manufacturing Technology Management, 30(8), 1127-1142. https://doi.org/10.1108/JMTM-01-2018-0008

Nguyen, X. T., \& Luu, Q. K. (2020). Factors affecting adoption of industry 4.0 by small- and medium-sized enteprises: A case in ho chi minh city, Vietnam. Journal of Asian Finance, Economics and Business, 7(6), 255-264. https://doi.org/10.13106/jafeb.2020.vol7.no6.25

Radzi, N. M., \& Wahab, A. S. E. (2017). Enhancing the competitiveness of Malaysian SMEs through technological capability: A perspective. The Social Sciences, 12(4), 719-724. 
SME Corporation Malaysia. (2017). SME Annual Report 2017/18. Retrieved from http://www.smecorp.gov.my/index.php/en/laporan-tahunan/3342-laporan-tahunanpks-2017-18

SME Corporation Malaysia. (2018). SME Report 2018. Retrived from http://www.smecorp.gov.my/index.php/en/resources/2015-12-21-11-07-06/smeannual-report

SME Corporation Malaysia. (2018). SME Definitions. Retrieved from https://www.smecorp.gov.my/index.php/en/policies/2020-02-11-08-01-24/smedefinition

Stentoft, J., Rajkumar, C., \& Madsen, E. S. (2017). Industry 4.0 in Danish Industry, Department of Entrepreneurship and Relationship Management. Kolding: University of Southern Denmark.

World Bank Group. (2018). Malaysia's Digital Economy: A New Driver of Development. Washington, DC: World Bank. License: Creative Commons Attribution. Retrieved from https://www.worldbank.org/en/country/malaysia/publication/malaysias-digitaleconomy-a-new-driver-of-development 